\title{
Invasion of Sargassum muticum in Limfjorden (Denmark) and its possible impact on the indigenous macroalgal community
}

\author{
Peter A. Stæhr ${ }^{1, *}$, Morten F. Pedersen ${ }^{1}$, Mads S. Thomsen ${ }^{1}$, Thomas Wernberg ${ }^{1}$, \\ Dorte Krause-Jensen ${ }^{2}$
}

\author{
${ }^{1}$ Department of Life Sciences and Chemistry, Roskilde University, Box 260, 4000 Roskilde, Denmark \\ ${ }^{2}$ National Environmental Research Institute, Department of Lake and Estuarine Ecology, Box 314, 8600 Silkeborg, Denmark
}

\begin{abstract}
Attached Sargassum muticum (Yendo) Fensholt was first observed in the westernmost part of Limfjorden (Denmark) in 1984, and it has since colonized Limfjorden from west to east at a rate of 15 to $17 \mathrm{~km} \mathrm{yr}^{-1}$. By 1997, S. muticum had become the most dominant macroalga, covering more than $6 \%$ of the bottom between 0 and $6 \mathrm{~m}$ depth, corresponding to ca $35 \%$ cover of the hard substrate. In 1990, the cover of S. muticum was strongly correlated with distance from the original source area in the westernmost part of the estuary, suggesting that colonization was still in progress. By 1997, the cover of $S$. muticum was less correlated with distance from the original source area and more strongly correlated with the amount of hard substrate, indicating that colonization was reaching its climax. The absence of $S$. muticum from certain parts of Limfjorden by 1997 is therefore best explained by lack of hard substrate in these areas, and not by insufficient colonization time. The increased abundance of S. muticum between 1990 and 1997 affected species richness and diversity of the macroalgal community only marginally. However, multivariate community analysis revealed significant changes in the macroalgal community structure that were closely related to the increased abundance of $S$. muticum. Not only did the dominance of $S$. muticum increase significantly from 1990 to 1997, but the cover of several indigenous species belonging to the genera Laminaria, Fucus, and Codium decreased during the same period, indicating competitive displacement through competition for hard substrate and light.
\end{abstract}

KEY WORDS: Sargassum muticum · Macroalgae $\cdot$ Invasion · Macroalgal community structure

\section{INTRODUCTION}

The introduction of alien plants and animals into new areas may affect the community structure through competitive displacement or even exclusion of indigenous species (Elton 1958, Mooney \& Drake 1986, Pieterse \& Murphy 1990, Berman et al. 1992, Vermeij 1996). The success of an invasive species depends on its mode of reproduction, growth rate and dis persive

*Present address: National Environmental Research Institute, Department of Marine Ecology, Box 358, 4000 Roskilde, Denmark. E-mail: pst@dmu.dk potential (Elton 1958, Mooney \& Drake 1986), but not all introduced species are aggressive, as introductions with little or no impact on the native communities have been reported, especially from marine and estuarine areas (Williamson \& Brown 1986, Berman et al. 1992, Vermeij 1996, Ruiz et al. 1997). Sargassum muticum (Yendo) Fensholt originates from Asia and was introduced to North America in the 1940s and to Europe in the early 1970s (Critchley 1983) and has subsequently spread along the Atlantic coast of western Europe from Portugal in the south to Scandinavia in the north (Rueness 1989, Karlsson \& Loo 1999). S. muticum was first observed in Denmark in the western part of Limfjorden 
in 1984 (Christensen 1984) and has since successfully colonized most of this estuary and is now spreading further into the Danish inland waters (WernbergMøller et al. 1998b).

The capacity of Sargassum muticum to spread and invade new areas seems to rely on a high reproductive potential and its ability to drift. $S$. muticum is monoecious, self-fertile and highly fecund (Norton 1977), and possesses vesicles that allow the annually produced fronds to drift when broken off. Although these drifting fronds do not reattach, they are able to survive and become fertile as they drift (Fletcher \& Fletcher 1975, Norton 1977, 1992), thus increasing the potential for long-range dispersal and colonization of new locations far from the source populations (Deysher \& Norton 1982).

Once established in a new area, Sargassum muticum can accumulate high biomass and may therefore be a strong competitor for space and light (e.g. Critchley et al. 1990). Experiments have indicated that successful settlement and initial development of germlings depend on the availability of cleared substrate with low or no competition from other algae (Deysher \& Norton 1982, de Wreede 1983, Critchley et al. 1987, Andrew \& Viejo 1998). When first established, however, S. muticum may efficiently prevent settling and development of other algae due to high recruit densities and fast growth (Ambrose \& Nelson 1982, De Wreede 1983, Critchley et al. 1990). Critchley et al. showed that the irradiance was reduced by $95 \%$ within the uppermost $5 \mathrm{~cm}$ of a dense $S$. muticum surface canopy, thus preventing understory algae to develop and thrive.

The ecological consequences of the Sargassum muticum invasions in North America and Europe are virtually unknown. Although several authors have suggested that the invasion of $S$. muticum may have had a significant impact on the structure of indigenous algal communities through competitive displacement and/or exclusion (e.g. Fletcher \& Fletcher 1975, Rueness 1989, Walker \& Kendrick 1998), observational and experimental evidence is still rather scarce (see however, Ambrose \& Nelson 1982, de Wreede 1983, Critchley et al. 1987, Viejo 1997).

Since 1989, the Danish Environmental Authorities have monitored 24 transects in Limfjorden, a shallow Danish estuary, and data from these transects provide a unique opportunity to test the possible effect of invading Sargassum muticum on the indigenous algal community. The objective of this study was to describe the temporal and spatial invasion patterns of $S$. muticum in Limfjorden from 1984 to 1997, with special emphasis on the period from 1990 to 1997, for which reliable survey data are available. The potential effect of increasing abundance of $S$. muticum on species richness, diversity and structure of the macroalgal community in
Limfjorden is analyzed. We test the hypothesis that areas of Limfjorden which have experienced a marked increase in $S$. muticum cover show changes in community structure through modifications in species diversity and composition of dominant algal species.

\section{MATERIALS AND METHODS}

Study site. Limfjorden (Fig. 1) connects the North Sea with Kattegat and covers an area of about $1500 \mathrm{~km}^{2}$. The average depth is $4.9 \mathrm{~m}$, with a maximum depth of $28 \mathrm{~m}$. The tidal range in Limfjorden is only about $\pm 10 \mathrm{~cm}$, but wind-induced variations can be larger. Salinity ranges from ca $32 \%$ in the western part of the estuary to ca $24 \%$ in the eastern part. Sand and mud with scattered stones and boulders make up the bottom of Limfjorden. The amount of hard substrate (i.e. stones larger than $10 \mathrm{~cm}$ in diameter) tends to be highest in the western and central regions of the estuary.

Invasion patterns. The study is based on data obtained from the Danish Monitoring Program under the Action Plan for the Aquatic Environment (MPAPAE).
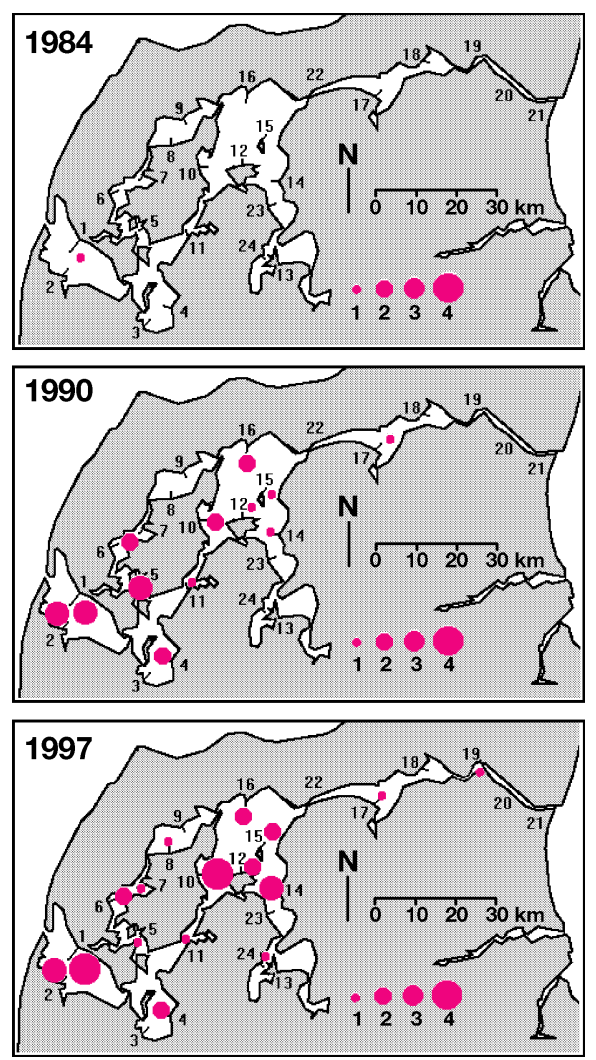

Fig. 1. Distribution of Sargassum muticum in Limfjorden in 1984, 1990 and 1997. 1: 0.1 to $1 \%$ cover; 2: 1 to $10 \%$ cover; 3: 10 to $30 \%$ cover; $4:>30 \%$ cover. Numbers 1-24: sample transects under MPAPAE program 
Table 1. Interval scale used in SCUBA surveys for ranking macroalgal cover and its conversion to numeric scale used in data analysis

\begin{tabular}{|lcc|}
\hline Rank & Interval scale (\%) & Numeric scale (\%) \\
\hline 0 & No registration & 0.0 \\
1 & $<2$ & 1.0 \\
2 & $2-25$ & 13.5 \\
3 & $25-50$ & 37.5 \\
4 & $50-75$ & 62.5 \\
5 & $75-100$ & 87.5 \\
\hline
\end{tabular}

Twenty-four sites (transects) in Limfjorden, each divided into 9 depth strata, were surveyed visually by the same SCUBA diver each summer from 1989 to 1997 (Limfjordsovervågningen 1997). The positions of the transects were identified by reference points on land and by geographic coordinates of landward and seaward positions by GPS. Within each depth stratum, the diver visually estimated species-specific cover of macroalgae on hard substrate using a modification of the Braun-Blanquet scale (Bullock 1996) presented in Table 1. Each depth interval was examined in a corridor of approximately $4 \mathrm{~m}$ width in the swimming direction. The diver estimated the proportion of bottom covered by hard substrate suitable for growth of perennial macroalgae (i.e. stones larger than $\sim 5$ to $10 \mathrm{~cm}$ in diameter) and the percent cover of each macroalgal species by visually projecting the outline of the algal surface perpendicularly to the substrate. Algal species which could not be identified in situ were identified in the laboratory. Algal cover was expressed as percent cover of suitable (i.e. hard) substrate within each depth stratum. Depth strata below $6 \mathrm{~m}$ were practically devoid of macroalgae throughout the entire estuary, so only data from the 5 uppermost strata (i.e. 0 to $6 \mathrm{~m}$ ) were used in the analysis. The ranks were transformed to a numerical scale and the total cover of each species per transect was then computed from data on substrate type and length of transects in each depth stratum. The cover of each species per unit hard substrate was finally computed for each entire transect.

Visual observations contain a subjective element and are less precise than more quantitative methods, but are often preferred when very large areas must be surveyed at relatively low cost (e.g. Meese \& Tomich 1992, Bullock 1996). Subjective methods have the potential problem that variability among divers may comprise a significant source of variation (Meese \& Tomich 1992, Middelboe et al. 1997). A comparison among different divers investigating the same transect showed that estimates of algal cover often diverged by \pm 1 rank order (corresponding to \pm 2 to $25 \%$ depending on abundance), while cover estimates of substrate type varied from \pm 0.75 to \pm 0.1 coefficient of variation (Middelboe et al. 1997). Such possible error in the Limfjord data is minimal since the same person performed all surveys between 1989 and 1997.

We illustrated the spatio-temporal invasion pattern of Sargassum muticum by mapping its abundance at each study site in 1984, 1990 and 1997. Temporal changes in total cover (averaged across all 24 transects, each year from 1990 to 1997) were tested by nonparametric ANOVA (Friedman's test for repeated measures: Zar 1996) and a simple time-series analysis of cover was performed using Spearman's rank correlation coefficient, $\mathrm{r}_{\mathrm{S}}$. Possible relationships between the total cover of $S$. muticum on each transect and environmental variables such as salinity (summer means), distance from original source area (Transect 1; Fig. 1), amount of hard substrate, and physical disturbance (weighted effective fetch, WEF) were tested by Spearman's rank-correlation analysis for each year. The fetch was determined for 8 compass bearings (N, NW, W, SW, S, SE, E, NE) and WEF was calculated according to Duarte \& Kalff (1986) as:

$$
\mathrm{WEF}=\sum_{i=1}^{8} F_{i} \times w f_{i}
$$

where $F_{i}$ is the fetch for Compass Bearing $i$, and $w f_{i}$ is the wind frequency for Bearing $i$. This expression takes into account both the morphometry of the estuary and the particular wind regime of the area studied. Data on wind directions and frequencies for 3 yr (1994 to 1997) were obtained from the Danish Meteorological Institute and averaged before being used in the WEF model.

Macroalgal community analysis. The possible impact of colonizing Sargassum muticum on the indigenous algal community was evaluated from changes in species richness, species diversity and community structure at 10 appointed transects from 1990 to 1997 . These transects were selected a priori according to the following criteria: (1) transects should have a high permanent or increasing cover of $S$. muticum between 1990 and 1997; (2) the transects should have a considerable amount of hard substrate (i.e. $>20 \%$ of the total substrate). According to these criteria Transects 1, 2, 4, $6,7,10,12,14,15$ and 16 (Fig. 1) were included in the analysis.

Species richness $(\mathrm{S})$ and diversity $(H)$ were estimated for each year and each transect. Diversity was calculated as the Shannon-Wiener index $\left(H^{\prime}\right)$ :

$$
H^{\prime}=-\sum p_{j} \times \ln \left(p_{j}\right)
$$

where $p_{j}$ is the proportion of total macroalgal cover of the $j$ th species.

Temporal changes in community structure were analyzed using non-parametric multivariate statistical 
analysis according to the guidelines provided by Clarke (1993). Non-parametric multi-dimensional scaling (nMDS) was used to illustrate the distance (i.e. dissimilarity) between community samples based on the Bray-Curtis similarity measure. One-way analysis of similarity (ANOSIM; Clarke \& Warwick 1994) was subsequently used to test whether the community structure differed significantly between years. The similarity percentages procedure (SIMPER) was then used to identify species that contributed most to the observed dissimilarity between years and also identified species that contributed most to the overall similarity among transects within each of the years (Clarke \& Warwick 1994). The multivariate analyses were performed using the PC software PRIMER (Plymouth Marine Laboratories, UK) on square-root transformed data.

Temporal changes in cover of functional groups or specific species of macroalgae were analyzed by non-parametric ANOVA (Friedman's test for repeated measures: Zar 1996) while correlation between cover of these groups or species and time or cover of Sargassum muticum were tested by Spearman's rank-correlation. For part of this analysis, species were grouped according to the functional-form model of Littler et al. (1983), with the modification that the original 6 groups were reduced to 5 by combining encrusting and calcareous algae.

\section{RESULTS}

\section{Distribution}

Sargassum muticum was first observed near Transect 1 in the western part of Limfjorden in 1984 (Christensen 1984), and colonization progressed eastwards, giving rise to small scattered populations in the easternmost part of the estuary in 1997 (Fig. 1). In 1990, S. muticum covered $3 \%$ of the total substrate between 0 and $6 \mathrm{~m}$ depth, and the cover progressively increased to $6 \%$ in 1997 (Fig. 2).

From the observations between 1984 and 1997 we have estimated an average dispersal rate of 15 to $17 \mathrm{~km}$ $\mathrm{yr}^{-1}$. Despite this rate of dispersal, some areas were left with very little or no Sargassum muticum in 1997 (e.g. Transects 8, 9, 11, 13, and 24; Fig. 1). The cover of $S$. muticum was strongly correlated with distance from the original source area, i.e. Transect $1 \quad r_{S}=-0.730$, $\mathrm{p}=0.001$; Table 2) in 1990, but the strength of this correlation decreased with time. In contrast, the correlation between cover of $S$. muticum and the amount of hard substrate increased from $0.533(\mathrm{p}=0.009)$ in 1990 to 0.746 ( $\mathrm{p}<0.0001)$ in 1997 . The cover of $S$. muticum was modestly and just significantly positively correlated with both salinity and WEF between 1990 and 1997 (Table 2).

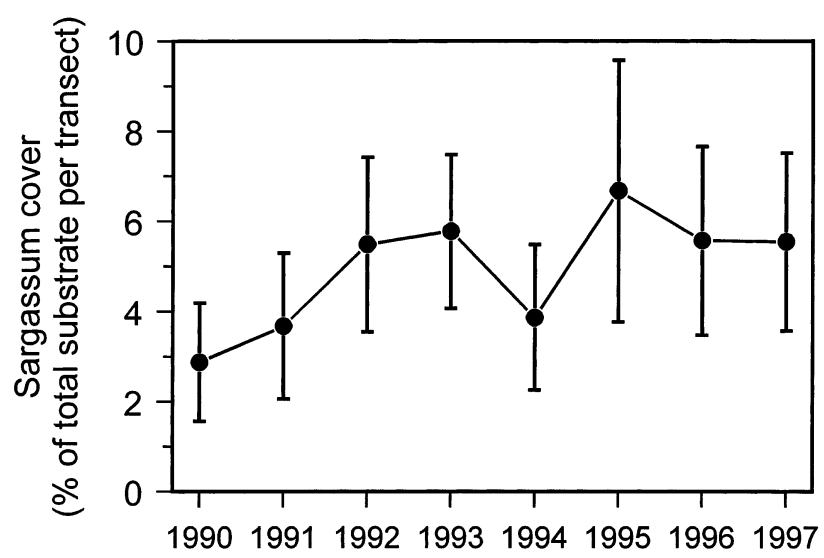

Fig. 2. Sargassum muticum. Temporal changes in average $( \pm 1 \mathrm{SE}, \mathrm{n}=24)$ percent cover across all 24 transects in Limfjorden from 1990 to 1997

The vertical distribution of Sargassum muticum was unimodal, with highest cover between 1 and $4 \mathrm{~m}$ depth (examples from 1990, 1993 and 1997 are shown in Fig. 3). The average cover of $S$. muticum increased significantly (Friedman's test, $\mathrm{p}<0.05$ ) in the depth interval 1 to $4 \mathrm{~m}$ from 1990 to 1997 , but remained constantly low in the depth intervals 0 to 0.5 and 4 to $6 \mathrm{~m}$. Correlation analysis revealed that amount of hard substrate was the only important regulating factor in both shallow $(0$ to $2 \mathrm{~m}$ ) and deep ( 2 to $6 \mathrm{~m})$ waters $\left(\mathrm{r}_{\mathrm{S}}=0.569\right.$, $\mathrm{p}<0.001$, and $\mathrm{r}_{\mathrm{S}}=0.627, \mathrm{p}<0.001$, respectively).

\section{Community analysis}

The average cover of Sargassum muticum on hard substrate (Fig. 4A) on the 10 transects selected for community analysis increased almost linearly from $16 \%$ in 1990 to $32 \%$ in 1993, resulting in a weak but significant correlation between cover of $S$. muticum and time

Table 2. Spearman's rank-correlation coefficients describing relationships between cover of Sargassum muticum and distance from source area, proportion of hard substrate on transects, salinity, and weighted effective fetch (WEF) in 1990, 1993 and 1997. Probability values are given in parentheses, $\mathrm{n}=24$ in all cases

\begin{tabular}{|lcccc|}
\hline Year, parameter & Distance & $\begin{array}{c}\text { Hard } \\
\text { substrate }\end{array}$ & Salinity & WEF \\
\hline 1990, S. muticum & -0.730 & 0.533 & 0.455 & 0.459 \\
cover vs & $(<0.001)$ & $(0.009)$ & $(0.026)$ & $(0.024)$ \\
1993, S. muticum & -0.717 & 0.567 & 0.410 & 0.333 \\
cover vs & $(<0.001)$ & $(0.004)$ & $(0.047)$ & $(0.112)$ \\
1997, S. muticum & -0.678 & 0.746 & 0.443 & 0.481 \\
cover vs & $(<0.001)$ & $(<0.001)$ & $(0.035)$ & $(0.017)$ \\
& & & & \\
\hline
\end{tabular}


Cover (\% of total substrate per transect)

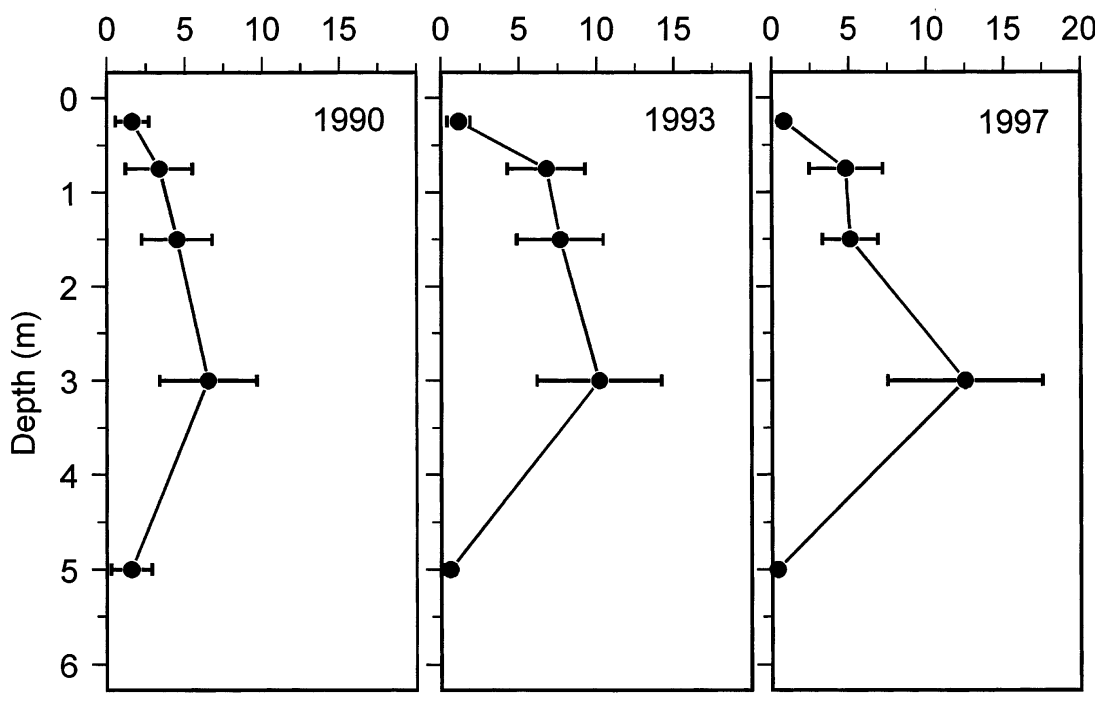

Fig. 3. Sargassum muticum. Vertical distribution (average $\pm 1 \mathrm{SE}, \mathrm{n}=24$ ) in Limfjorden in 1990, 1993 and 1997, based on data from all 24 transects scales of more than 2 to $3 \mathrm{yr}$. The same pattern, but less significant $(p=0.007$, data not shown), was evident when the data for $S$. muticum were removed from the data set, suggesting that community structure was affected both by the increasing abundance of $S$. muticum and by changes in the remaining community.

The species contributing most to the observed net dissimilarity between 1990 and 1997 were identified by the SIMPER procedure (Table 4). Sargassum muticum contributed most $(8.0 \%)$ to the observed dissimilarity due to its marked increase in cover. Other species, such as Ralfsia verrucosa (6.2\%), Phymatolithon lenormandii (5.4\%), Chondrus crispus $(4.4 \%)$ and Corallina officinalis $(3.8 \%)$ did, however, also contribute to the observed change in community structure through increased average abundance and/or evenness between 1990 and 1997. The contributions

$\left(\mathrm{r}_{\mathrm{S}}=0.313, \mathrm{p}=0.005\right)$. Average species richness $(\mathrm{S})$ remained constant at about 16 species from 1990 to $1997\left(\mathrm{r}_{\mathrm{S}}=-0.141, \mathrm{p}=0.804\right.$, Fig. 4B), while species diversity $\left(H^{\prime}\right)$ tended to decrease slightly with time $\left(\mathrm{r}_{\mathrm{S}}=-0.212, \mathrm{p}=0.059\right.$, Fig. $\left.4 \mathrm{C}\right)$.

The observed increase in cover of Sargassum muticum was followed by a change in average community structure across the 10 transects (Fig. 5A). The ordination of individual transects (Fig. 5B) shows that the community structure tended to cluster over time (i.e. variation among transects decreased), suggesting that the 10 transects became more similar in species composition as $S$. muticum increased in importance. The change in community structure between 1990 and 1997 was confirmed by the ANOSIM (overall $\mathrm{p}<0.001$; Table 3). Year-to-year changes in community structure were small, and significant changes appeared only when community structure was compared over time

Table 3. Summary (probability values) of 1-way analysis of similarities (ANOSIM) comparing community structure between 1990 and 1997. Overall probability (p) was <0.001

\begin{tabular}{|llllllll|}
\hline Year & 1991 & 1992 & 1993 & 1994 & 1995 & 1996 & 1997 \\
\hline 1990 & 0.634 & 0.379 & 0.275 & 0.072 & 0.007 & 0.001 & $<0.001$ \\
1991 & & 0.513 & 0.275 & 0.039 & 0.014 & 0.015 & $<0.001$ \\
1992 & & & 0.388 & 0.012 & 0.016 & 0.003 & $<0.001$ \\
1993 & & & & 0.284 & 0.201 & 0.010 & 0.015 \\
1994 & & & & & 0.207 & 0.001 & 0.004 \\
1995 & & & & & & 0.095 & 0.024 \\
1996 & & & & & & & 0.004 \\
\hline
\end{tabular}

by Laminaria saccharina $(5.2 \%)$, Dictyota dichotoma $(4.9 \%)$, Ceramium rubrum $(4.4 \%)$, Fucus serratus $(4.1 \%)$, F. vesiculosus $(3.5 \%)$, Codium fragile $(3.2 \%)$

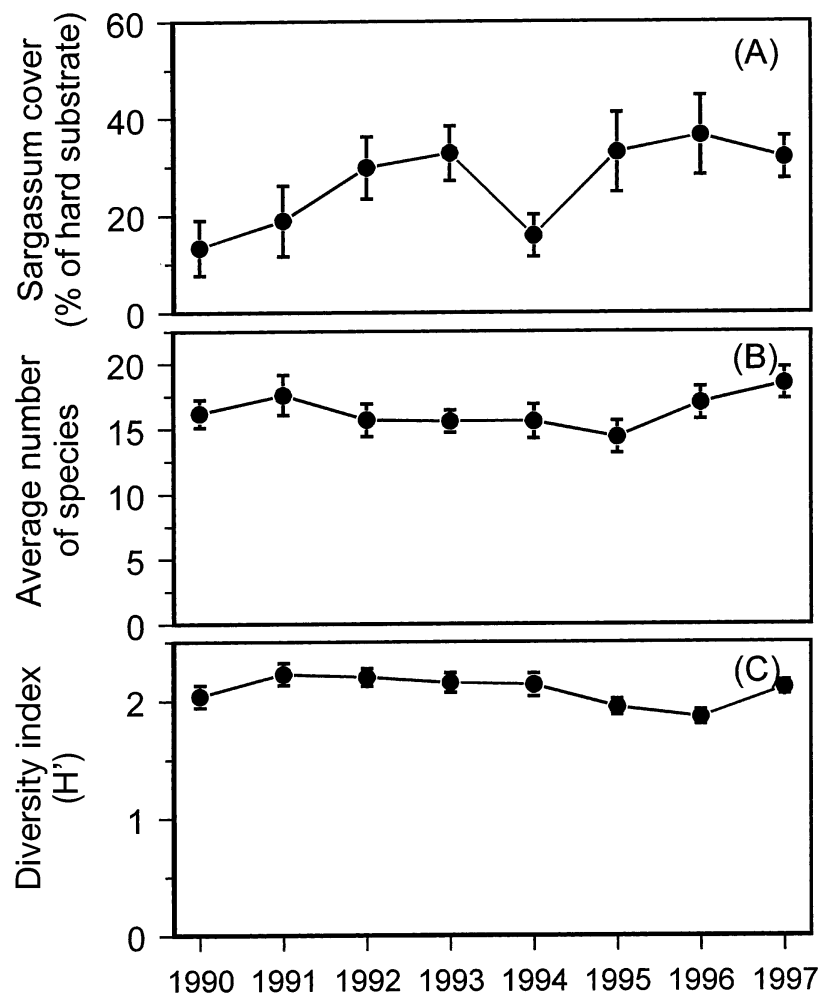

Fig. 4. (A) Changes in cover of Sargassum muticum (per unit hard substrate); (B) species richness (S); (C) species diversity $\left(H^{\prime}\right)$ from 1990 to 1997 , based on data from 10 transects selected for community analysis. All data are average \pm 1 SE $(n=10)$ 

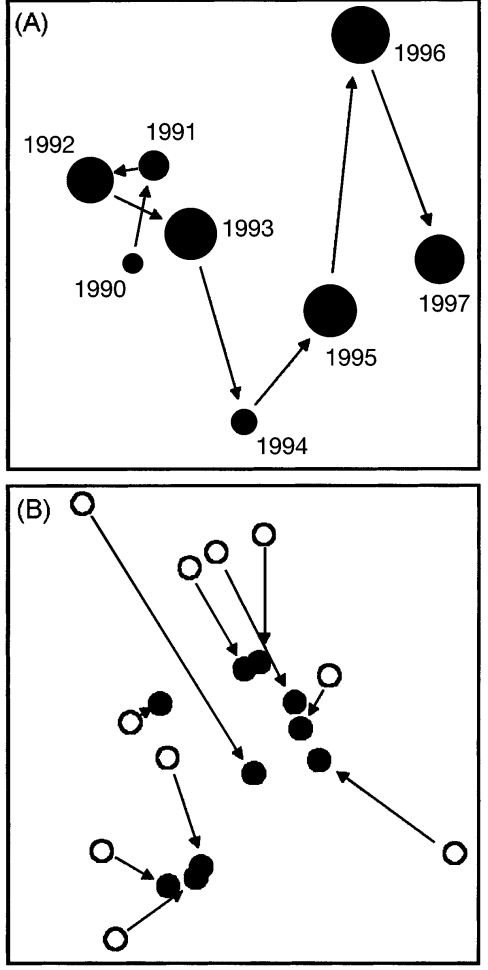

Fig. 5. nMDS (non-parametric multi-dimensional scaling) plots showing (A) temporal changes in average community structure (across 10 transects) from 1990 to 1997 (stress = 0.06) and (B) net changes in community structure at each of the transects from $1990(\mathbf{O})$ to $1997(\mathbf{O})$ (stress $=0.17$ ). Sizes of circles in (A) reflect amount of average cover of Sargassum muticum on the 10 transects
Table 5. Relative species contribution (\%) to overall similarity between transects within 3 yr: 1990, 1993 and 1997, determined using SIMPER analysis. Assignment of each species to functional groups is in parentheses $(\mathrm{Ca}=$ calcareous/crustose, $\mathrm{CB}=$ coarsely branched, $\mathrm{Fi}=$ filamentous, $\mathrm{Fo}=$ foliose, $\mathrm{L}=$ leathery)

\begin{tabular}{|lrrr|}
\hline Species & 1990 & 1993 & 1997 \\
\hline Sargassum muticum (L) & 11.8 & 23.8 & 27.3 \\
Laminaria saccharina (L) & 13.6 & 7.1 & $<1.0$ \\
Ralfsia verrucosa (Ca) & 1.2 & 3.7 & 8.4 \\
Dictyota dichotomy (Fo) & 2.3 & 3.3 & 1.2 \\
Ceramium strictum (Fi) & $<1.0$ & 3.0 & $<1.0$ \\
Chorda filum (CB) & 1.5 & $<1.0$ & 1.9 \\
Phymatolithon lenormandii (Ca) & $<1.0$ & 3.7 & 8.4 \\
Chondrus crispus (CB) & 15.8 & 10.0 & 10.6 \\
Halidrys siliquosa (L) & 2.8 & 1.4 & 2.5 \\
Ceramium rubrum (Fi) & 3.8 & 8.7 & 6.4 \\
Fucus serratus (L) & 3.8 & 4.9 & 3.4 \\
Codium fragile (CB) & 6.9 & 3.0 & 3.8 \\
Ectocarpus siliculosus (Fi) & $<1.0$ & $<1.0$ & 2.0 \\
Fucus vesiculosus (L) & 6.4 & 6.1 & 2.4 \\
Corallina officinalis (Ca) & 6.8 & 12.9 & 8.1 \\
Overall similarity & 33.4 & 46.7 & 50.5 \\
& & & \\
\hline
\end{tabular}

and Halidrys siliquosa (3.1\%) were driven by a significant decrease in average cover and/or evenness of these species over the same period.

The contribution of each species to the similarity among the 10 transects in 1990, 1993 and 1997, is given in Table 5. Chondrus crispus (15.8\%), Laminaria saccharina (13.6\%) and Sargassum muticum (11.8\%) contributed most to overall similarity (33.4) between transects in 1990. By 1997, the similarity among transects had increased to 50.5 , and $S$. muticum $(27.3 \%)$ had become the most abundant and evenly distributed species, thus adding much more to the overall similarity than any other species. The only types of algae that tended to decrease consistently over the same period were members of the coarsely branched and thick leathery algae.

The cover of most functional-form groups changed considerably as the cover of Sargassum muticum increased from 1990 to 1997 (Fig. 6). The cover of most groups increased from 1990 to 1991/1992, but then tended to decline again. At stations dominated by $S$. muticum, the cover of coarsely branched $\left(\mathrm{r}_{\mathrm{S}}=-0.283, \mathrm{p}=0.011\right)$ and thick leathery algae $\left(\mathrm{r}_{\mathrm{S}}=-0.488, \mathrm{p}<0.001\right)$ was negatively correlated with time over the entire period 1990 to 1997, while no such decline was observed at sta- 


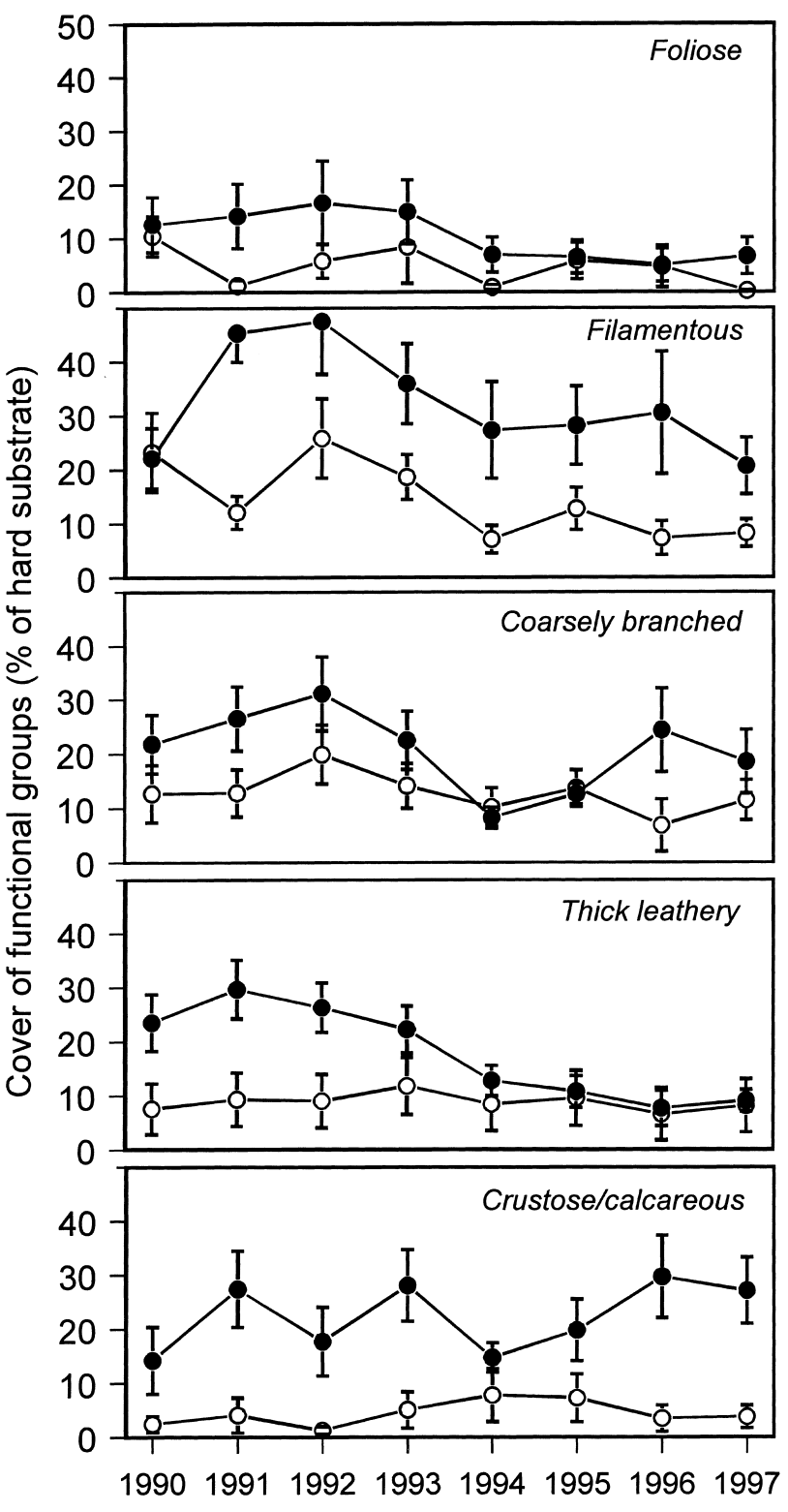

Fig. 6. Temporal changes in average cover (per unit hard substrate) of functional-form groups from 1990 to 1997. (O) Data from 10 stations selected for community analysis (average $\pm 1 \mathrm{SE}, \mathrm{n}=10) ;(\mathrm{O})$ data from remaining 14 stations with little or no Sargassum muticum (average $\pm 1 \mathrm{SE}, \mathrm{n}=14$ )

tions without or with very little $S$. muticum (Fig. 6). The cover of filamentous algae was not correlated to time between 1990 and 1997 (Table 6) but was negatively correlated to time between 1992 and $1997\left(\mathrm{r}_{\mathrm{S}}=-0.286\right.$, $\mathrm{p}=0.027$ ). The decline in cover of filamentous algae from 1992 to 1997 was, however, also evident at stations without or with very little $S$. muticum (Fig. 6), inferring that the decline was not caused by competi-
Table 6. Spearman's rank-correlation coefficients $\left(\mathrm{r}_{\mathrm{S}}\right)$ describing relationships between cover of functional-form groups of algae Sargassum muticum, Laminaria saccharina, Codium fragile, Halidrys siliquosa, Fucus serratus and F. vesiculosus and time or $S$. muticum cover. Based on data from 10 transects selected for community analysis, $n=80$ (1990 to 1997) in all cases

\begin{tabular}{|lrr|}
\hline Parameter & \multicolumn{1}{c|}{$\mathrm{r}_{\mathrm{S}}$} & \multicolumn{1}{c|}{$\mathrm{p}$} \\
\hline Foliose vs Time & -0.193 & 0.086 \\
Filamentous vs Time & -0.214 & 0.057 \\
Coarsely branched vs Time & -0.283 & 0.011 \\
Thick leathery vs Time & -0.488 & $<0.001$ \\
Crustose/calcareous vs Time & 0.195 & 0.084 \\
Sargassum muticum vs Time & 0.313 & 0.005 \\
Laminaria saccharina vs Time & -0.750 & $<0.001$ \\
Codium fragile vs Time & -0.338 & 0.006 \\
Halidrys siliquosa vs Time & -0.326 & 0.038 \\
Fucus serratus vs Time & -0.063 & 0.646 \\
Fucus vesiculosus vs Time & -0.284 & 0.016 \\
L. saccharina vs S. muticum & -0.286 & 0.023 \\
C. fragile vs $S$. muticum & -0.255 & 0.044 \\
H. siliquosa vs $S$. muticum & 0.230 & 0.154 \\
F. serratus vs $S$. muticum & -0.353 & 0.008 \\
F. vesiculosus vs $S$. muticum & -0.411 & $<0.001$ \\
& & \\
\hline
\end{tabular}

tion from $S$. muticum. The cover of foliose and crustose/calcareous algae was not correlated with time (Fig. 6, Table 6).

The reduced cover of coarsely branched and thick leathery algae resulted mainly from a significant decline among Laminaria saccharina, Codium fragile, Halidrys siliquosa and Fucus vesiculosus (Fig. 7, Table 6). It is noteworthy that these species did not undergo a similar decline at stations without or with very little Sargassum muticum (Fig. 7). The cover of $L$. saccharina, $C$. fragile, $F$. vesiculosus and $F$. serratus were further inversely correlated with the cover of $S$. muticum during the same period, thus indicating competitive interaction between $S$. muticum and these species (Table 6).

\section{DISCUSSION}

Sargassum muticum has successfully colonized most suitable areas of Limfjorden since it was first observed in 1984. It is unclear how S. muticum was first introduced, but transplantation of live oysters for mariculture is often mentioned as a likely dispersal vector (e.g. Critchley \& Dijkema 1984). Oysters (Ostrea edulis and Crassostrea gigas) were imported from France and transplanted in Limfjorden during the early 1980s, concomitant with the first observations of $S$. muticum. However, $S$. muticum had also been introduced to the southwestern parts of Sweden and Norway by the end of the 1980s (Rueness 1989, Karlsson \& Loo 1999), and 


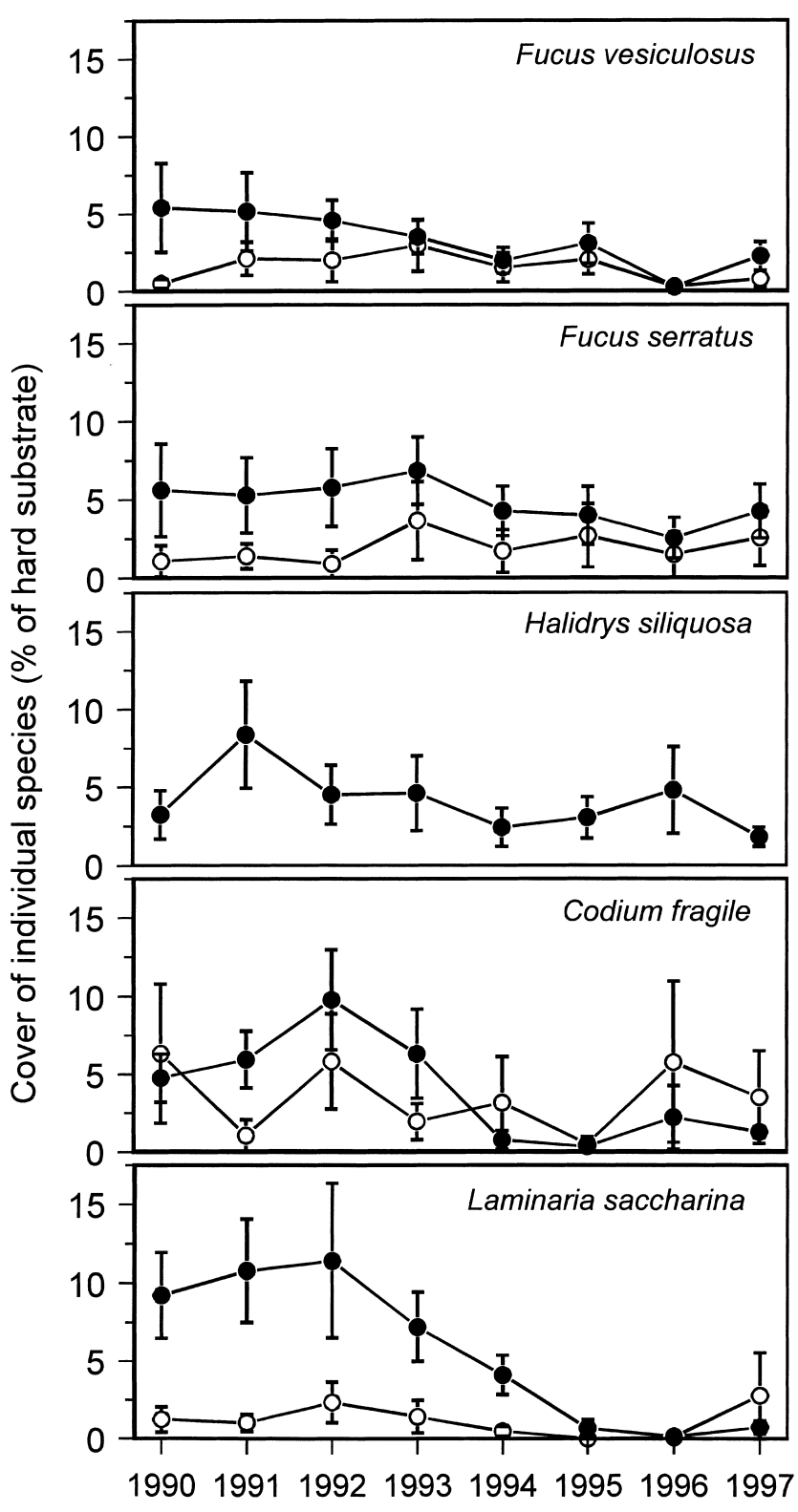

Fig. 7. Temporal changes in average cover (per unit hard substrate) of 5 thick, slow-growing species from 1990 to 1997. (๑) Data from the 10 stations selected for community analysis, (average $\pm 1 \mathrm{SE}, \mathrm{n}=10$ ); (O) data from remaining 14 stations with little or no Sargassum muticum (average $\pm 1 \mathrm{SE},(\mathrm{n}=14)$

(stations without $S$. muticum had no Halidrys siliquosa)

neither of these localities received live oysters for transplantation as far as we are informed. The sites in Scandinavia where $S$. muticum was initially observed are located directly on the hydrographical path leading from the populations in the Channel area and the Netherlands, and $S$. muticum has often been found washed up on the islands of the Frisian Wadden Sea (Schories et al. 1997). Thus, introduction by way of drifting fronds being carried along the west coast of
Jutland from the Channel area cannot be ruled out, as drifting is considered important in the long-range dispersal of S. muticum (Deysher \& Norton 1982).

Drift of fertile fronds is also considered important for dispersal and establishment of Sargassum muticum populations on the regional scale (e.g. Farnham et al. 1981, Critchley \& Dijkema 1984). Farnham et al. reported that $S$. muticum colonized new areas with a speed of ca $30 \mathrm{~km} \mathrm{yr}^{-1}$, which is in the same order of magnitude as in the present study (15 to $17 \mathrm{~km} \mathrm{yr}^{-1}$ ). The fast colonization of $S$. muticum in Limfjorden does indicate that the prime mode of dispersal was by detached fronds floating along the predominantly eastward winds and currents, because the dispersal range of propagules from attached specimens of Sargassum spp. is limited to a few metres only (Deysher \& Norton 1982, Kendrick \& Walker 1991). Although S. muticum has spread from west to east in Limfjorden within $13 \mathrm{yr}$, some areas were still devoid of $S$. muticum in 1997. The observed speed of dispersal show, however, that $S$. muticum must have had sufficient time to become established in all parts of Limfjorden, and today's absence of $S$. muticum from certain areas is, therefore, most likely a result of physico-chemical and/or biological barriers, rather than insufficient colonization time.

The strong inverse correlation between cover of Sargassum muticum and distance from the original source area in 1990 suggests that the establishment and development of the $S$. muticum populations in Limfjorden were still in progress during the early 1990s. The strength of this correlation decreased, however, from 1990 to 1997 , indicating that the invasion had been completed by the late 1990s and that other factors then became more important for the distribution pattern.

The distribution pattern of Sargassum muticum in Limfjorden by the late 1990s may have been determined by lack of hard substrate, low salinity and/or high physical disturbance due to wave action. The increasing strength of the correlation between cover of S. muticum and the amount of hard substrate between 1990 and 1997 suggest that lack of hard substrate plays an important role. S. muticum prefers hard substrate to settle and develop, and Wernberg-Møller et al. (1998a) showed that the abundance of $S$. muticum in Limfjorden was significantly related to substrate composed by stones with a diameter larger than ca $10 \mathrm{~cm}$, whereas smaller stones, gravel and sand were unsuitable substrate for grown specimens. The increase in cover of $S$. muticum leveled off in 1995, indicating that the carrying capacity had been reached. The strong correlation between cover and amount of hard substrate in 1997 suggests, therefore, that lack of available substrate limits further expansion of $S$. muticum in Limfjorden. Clearing experiments (Deysher \& Norton 1982, de 
Wreede 1983, Viejo 1997) have shown, however, that $S$. muticum can benefit from catastrophic events whereby hard substrates are cleared of other algae by physical disturbance, because it can regenerate fast from its basal part and because its recruits seem to be superior competitors compared to recruits of most other species. $S$. muticum may, therefore, be able to affect the reestablishment of other species after future disturbances (de Wreede 1983, Critchley et al. 1987) and thus increase its abundance further.

Grown Sargassum muticum populations cannot be sustained for prolonged periods at salinities below 15\%, since reproduction becomes impaired (Kjeldsen \& Pinney 1972, Steen 1992). Although weak salinity gradients do exist in Limfjorden, the salinities recorded were always above $24 \%$ and salinity does therefore not seem to restrict today's distribution of $S$. muticum. Physical disturbance by waves may also restrict growth and survival of $S$. muticum on exposed shores (Viejo et al. 1995, Andrew \& Viejo 1998). The effective fetch in Limfjorden is, however, rather short compared to that of the Atlantic coast, and wave exposure does therefore not seem to restrict the distribution of $S$. muticum in Limfjorden. Instead, the cover of $S$. muticum was weakly and positively correlated with exposure (WEF) in Limfjorden. In summary, the amount of hard substrate available seems to be the most important controlling factor for the present-day distribution of $S$. muticum.

The western and central parts of Limfjorden experienced the most marked increase in cover of Sargassum muticum between 1990 and 1997, but species number and diversity of the macroalgal community were only marginally affected. The continuous increase in cover of S. muticum from 1990 to 1997 caused diversity $\left(H^{\prime}\right)$ to decrease slightly, partly because $S$. muticum became more dominant, partly because the cover of certain other species declined during the same period. The ANOSIM confirmed that changes in community structure took place between 1990 and 1997 and the SIMPER analysis (Table 4) identified $S$. muticum as being mainly responsible for the observed net dissimilarity and, thus, for the change in community structure in general. The change in community structure could have been driven by the increased dominance of $S$. muticum alone, but the SIMPER analysis showed that the dominance patterns of other macroalgae changed too. Hence, as S. muticum increased its contribution to the similarity among transects between 1990 and 1997 (Table 5), the contribution of Laminaria saccharina, Codium fragile, Fucus vesiculosus and other species decreased, indicating a potential interaction between S. muticum and those species.

In accordance with the results of the community analysis, we found that the cover of coarsely branched and thick leathery algae decreased from the early 1990s to 1997 after Sargassum muticum had reached maximum cover. The reduced cover of thick, slowgrowing algae was mainly driven by a significant decline in Laminaria saccharina, Codium fragile, Halidrys siliquosa, Fucus vesiculosus and other algal species. These findings suggest that the invasion and establishment of $S$. muticum in Limfjorden have affected the local algal community through competitive interactions between S. muticum and several slowgrowing algae. This interpretation is further supported by the negative correlation between cover of $S$. muticum and many of these algae (Table 6).

Our results are comparable to those of Viejo (1997), who found that invading Sargassum muticum reduced the presence of leathery and foliose algae in tidepools along the Atlantic coast of northern Spain. Other studies have indicated strong competitive interactions between $S$. muticum and other algae. Deysher \& Norton (1982) found that dense populations of naturally occurring algae prevented settlement and development of $S$. muticum, thus indicating that juvenile $S$. muticum is a poor competitor relative to grown specimens of other algae. On the other hand, Ambrose \& Nelson (1982) and de Wreede (1983) found that dense populations of adult $S$. muticum could restrict settlement and early development of leathery and filamentous algae such as Macrocystis pyrifera and Rhodomela larix, respectively, indicating that, as competitors, grown specimens of $S$. muticum are superior to juveniles of many other algae. We also found a weak decline in the cover of foliose and filamentous algae between 1992 and 1997, indicating competitive interference between $S$. muticum and these groups. However, these declines were probably not caused by the invasion of $S$. muticum, since similar declines were observed at stations with very little or no $S$. muticum.

We conclude that the invasion of Sargassum muticum in Limfjorden has affected the local algal community through competition with members of the thick leathery and coarsely branched algae. The reproduction strategy and canopy structure of $S$. muticum indicates that competition must be mainly for space and light, as also suggested by Viejo (1997). We are aware that our conclusion is based mainly on correlative evidence, which does not necessarily infer causal relationships, and experimental evidence is needed to confirm the existence of competitive interaction between S. muticum and other species of macroalgae and to identify the resources for which they compete.

Acknowledgements. We would like to thank Martha Laursen, The County of Ringkøbing, Karsten Dahl, National Environmental Research Institute, Department of Marine Ecology, and 4 anonymous referees for valuable discussions and suggestions. 


\section{LITERATURE CITED}

Ambrose RF, Nelson BV (1982) Inhibition of giant kelp recruitment by an introduced brown alga. Bot Mar 25: 265-267

Andrew NL, Viejo RM (1998) Ecological limits to the invasion of Sargassum muticum in northern Spain. Aquat Bot 60:251-263

Berman J, Harris L, Buttrick M (1992) Recent invasions of the Gulf of Maine: three contrasting ecological histories. Conserv Biol 6:435-441

Bullock J (1996) Plants. In: Sutherland WJ (ed) Ecological census techniques, a handbook. Cambridge University Press, Cambridge, p 111-138

Christensen T (1984) Sargassotang, en ny algeslægt i Danmark. Urt 8(4):99-104 (in Danish)

Clarke KR (1993) Non-parametric multivariate analysis of changes in community structure. Aust J Ecol 18:117-143

Clarke KR, Warwick RM (1994) Change in marine communities: an approach to statistical analysis and interpretation. Bourne Press Limited, Bournemouth

Critchley AT (1983) Sargassum muticum: a taxonomic history including world-wide and western Pacific distributions. J Mar Biol Assoc UK 63:617-625

Critchley AT, Dijkema R (1984) On the presence of the introduced brown alga Sargassum muticum, attached to commercially imported Ostrea edulis in the SW Netherlands. Bot Mar 27:211-216

Critchley AT, Nienhuis PH, Verschuure K (1987) Presence and development of populations of the introduced brown alga Sargassum muticum in the southwest Netherlands. Hydrobiologia 151/152:245-255

Critchley AT, de Visscher PRM, Nienhuis PH (1990) Canopy characteristics of the brown alga Sargassum muticum (Fucales, Phaeophyta) in Lake Grevelingen, southwest Netherlands. Hydrobiologia 204/205:211-217

de Wreede RE (1983) Sargassum muticum (Fucales, Phaeophyta): regrowth and interaction with Rhodomela larix (Ceraminales, Rhodophyta). Phycologia 22:153-160

Deysher LE, Norton TA (1982) Dispersal and colonisation in Sargassum muticum (Yendo) Fensholt. J Exp Mar Biol Ecol 56:179-195

Duarte CM, Kalff J (1986) Littoral slope as a predictor of the maximum biomass of submerged macrophyte communities. Limnol Oceanogr 31:1072-1080

Elton CS (1958) The ecology of invasions by animals and plants. Methuen \& Co Ltd, London

Farnham WF, Murfin C, Critchley AT, Morrell S (1981) Distribution and control of the brown alga Sargassum muticum. In: Leuring T (ed) Proc 10th Int Seaweed Symp. Gruyter \& Co, Berlin, p 277-282

Fletcher RL, Fletcher SM (1975) Studies on the recently introduced brown alga Sargassum muticum (Yendo) Fensholt I. Ecology and reproduction. Bot Mar 18:149-156

Karlsson J, Loo LO (1999) On the distribution and the continuous expansion of the Japanese seaweed Sargassum muticum in Sweden. Bot Mar 42:285-294

Kendrick GA, Walker DI (1991) Dispersal distances for propagules of Sargassum spinuligerum (Sargassaceae, Phaeophyta) measured directly by vital staining and venturi suction sampling. Mar Ecol Prog Ser 79:133-138
Kjeldsen CK, Pinney HK (1972) Effects of variations in salinity and temperature on some estuarine macroalgae. In: Nisizawa K (ed) Proc 7th Int Seaweed Symp. University of Toleyo Press, Tokyo, p 301-308

Limfjordsovervågningen (1997) Bundvegetation, Limfjorden 1996. Udført af Bio/consult, Ringkjøbing, Uiborg og Nordjyllands Amter, Ringkjøbing (in Danish)

Littler MM, Littler DS, Taylor PR (1983) Evolutionary strategies in a tropical barrier reef system: functional-form groups of marine macroalgae. J Phycol 19:229-237

Meese RJ, Tomich PA (1992) Dots on the rocks: a comparison of percent cover estimation methods. J Exp Mar Biol Ecol 165:59-73

Middelboe AL, Krause-Jensen D, Nielsen K, Sand-Jensen K (1997) Interkalibrering af bundvegetationsundersøgelser (in Danish). Faglig rapport fra DMU, nr 220. Miljø og Energiministeriet, Danmarks Miljøundersøgelser, Silkeborg

Mooney HA, Drake JA (1986) Ecology of biological invasions of North America and Hawaii. Ecol Stud 58:1-321

Norton TA (1977) Ecological experiments with Sargassum muticum. J Mar Biol Assoc UK 57:33-43

Norton TA (1992) Dispersal by macroalgae. Br Phycol J 27: 293-301

Pieterse AH, Murphy KJ (1990) Aquatic weeds. Oxford University Press, Oxford

Rueness J (1989) Sargassum muticum and other introduced Japanese macroalgae: biological pollution of European coasts. Mar Pollut Bull 20:173-176

Ruiz GM, Carlton JT, Grosholz ED, Hines AH (1997) Global invasions of marine and estuarine habitats by non-indigenous species: mechanisms, extent, and consequences. Am Zool 37:621-632

Schories D, Albrecht A, Lotze H (1997) Historical changes and inventory of macroalgae from Königshafen Bay in the northern Wadden Sea. Helgol Meeresunters 51:321-341

Steen H (1992) Sargassum muticum i Norge: årsyklus og utbredelse i relasjon til toleranse overfor regulerende miljøfaktorer. MSc thesis, University of Oslo (in Norwegian)

Vermeij GJ (1996) An agenda for invasion biology. Biol Conserv 78:3-9

Viejo RM (1997) The effects of colonization by Sargassum muticum on tidepool macroalgal assemblages. J Mar Biol Assoc UK 77:325-340

Viejo RM, Arrontes J, Andrew NL (1995) An experimental evaluation of the effect of wave action on the distribution of Sargassum muticum in northern Spain. Bot Mar 38: 437-441

Walker DI, Kendrick GA (1998) Threats to macroalgal diversity: marine habitat destruction and fragmentation, pollution and introduced species. Bot Mar 41:105-112

Wernberg-Møller T, Thomsen MS, Stæhr PA (1998a) Ecology of Sargassum muticum (Yendo) Fensholt in Limfjorden MSc thesis, Roskilde University

Wernberg-Møller T, Thomsen MS, Stæhr PA (1998b) Invasion af butblæret sargassotang i Danmark - status anno 1998. Urt 22(4):128-132 (in Danish)

Williamson MH, Brown KC (1986) The analysis and modeling of British invasions. Phil Trans R Soc (Ser B) 314:505-522

Zar JH (1996) Biostatistical analysis, 3rd edn. Prentice Hall Upper Saddle River, NJ

Submitted: September 27, 1999; Accepted: May 23, 2000

Proofs received from author(s): October 20, 2000 